\title{
Malignant peripheral ameloblastoma arising from the gingiva: A case report
}

\author{
Jasmine Saleh ${ }^{1}$, Laura Malone², John C. Papadimitriou*2 \\ ${ }^{1}$ Department of Otolaryngology-Head and Neck Surgery, University of Michigan, Ann Arbor, United States \\ ${ }^{2}$ Department of Pathology, University of Maryland Medical Center, Baltimore, United States
}

Received: November 26, 2017

Accepted: January 1, 2018

Online Published: January 27, 2018

DOI: $10.5430 /$ crcp.v5n1p1

URL: https://doi.org/10.5430/crcp.v5n1p1

\begin{abstract}
Ameloblastomas account for $9 \%-11 \%$ of all odontogenic tumors and usually arise from the mandible. Peripherally arising ameloblastomas are exceedingly rare, comprising 1\%-2\% of all ameloblastomas. We present a case of peripheral ameloblastoma with malignant differentiation in a 72-year-old male patient. The patient underwent a biopsy of the left palatoglossal fold, and histological examination of the specimen demonstrated a well differentiated squamous cell carcinoma in situ with at least superficially invasive growth and features suggestive of peripheral ameloblastic carcinoma. The patient chose radiation therapy as opposed to surgical excision.
\end{abstract}

Key Words: Peripheral ameloblastoma, Ameloblastoma, Gingiva, Peripheral

\section{INTRODUCTION}

Ameloblastomas are rare, benign epithelial odontogenic tumors involving the jaw, with an incidence of 0.5 cases per million individuals per year. ${ }^{[1,2]}$ They account for $1 \%$ of all oral ectodermal tumors and $9 \%-11 \%$ of all odontogenic tumors. ${ }^{[1]}$ While approximately $80 \%$ of the cases arise from the mandible, $1 \%-2 \%$ of all ameloblastomas are peripheral and develop in extraosseous locations. ${ }^{[1,3]}$ We represent a case of peripheral ameloblastoma arising from gingiva in a 72-year-old male patient.

\section{CASE REPORT}

A 72-year-old male with a history of non-Hodgkin's lymphoma of the right upper extremity status post treatment with rituximab and radiation, in remission since 2010, and a 87.50 pack-year smoking history presented with a lesion in his left retromolar trigone. On examination, a $3.0 \mathrm{~cm} \times$ $2.0 \mathrm{~cm}$ raised, verrucous-type lesion with a rough, erythematous surface was noted. A biopsy of the lesion was taken, and histological examination revealed islands of epithelial cells and stellate reticulum surrounded by peripherally palisading columnar cells, which was consistent with the follicular type of ameloblastoma. Significant nuclear pleomorphism and hyperchromasia, high mitotic rate, squamous metaplasia with keratin pearl formation, and cystic degeneration within the nests of epithelial cells, which were suggestive of ameloblastic carcinoma, were also observed in the biopsy (see Figure 1). The lesion was found to be connected to and continuous with the overlying gingival mucosa. There was no bone present within the biopsy for evaluation. The patient chose to receive radiation therapy instead of surgical resection and will be continuously followed-up.

*Correspondence: John C. Papadimitriou, M.D, Ph.D, Professor; Email: jpapa001@ umaryland.edu; Address: Department of Pathology, University of Maryland Medical Center, Baltimore, MD 21287, United States. 

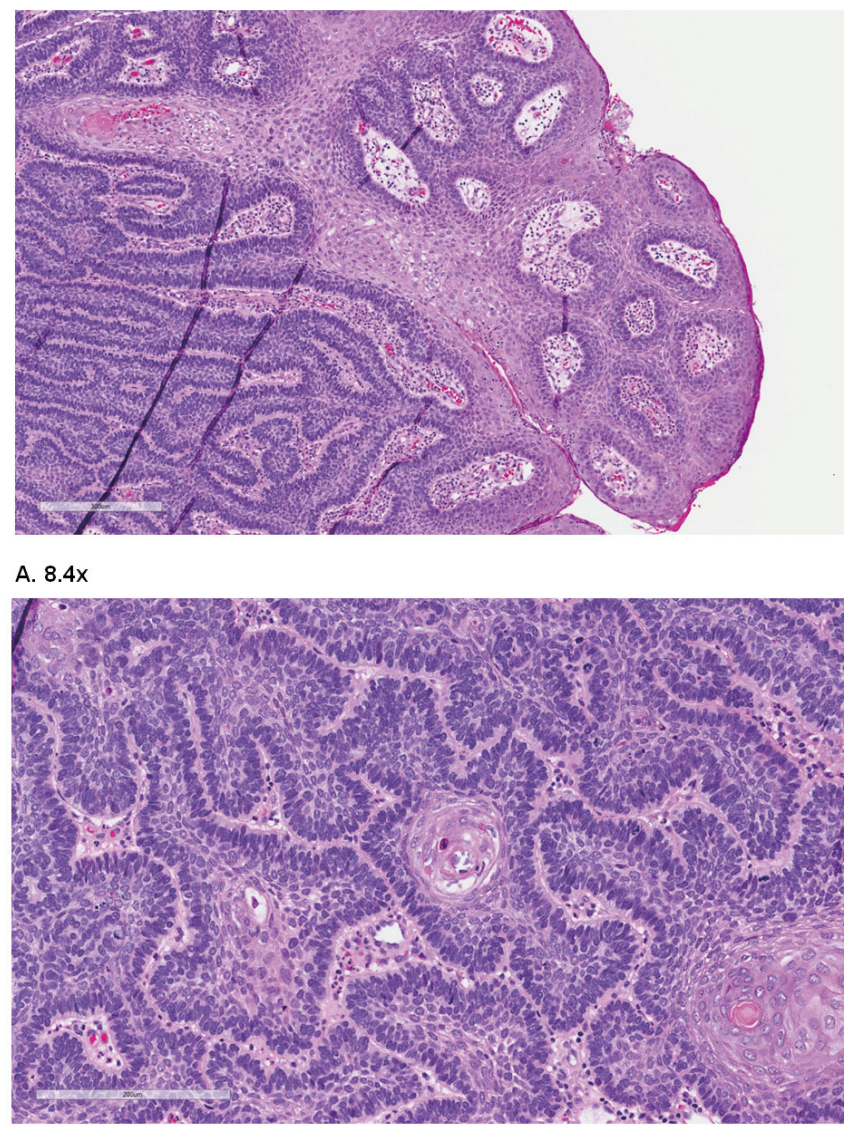

B. $20 x$

Figure 1. Histological examination demonstrated squamous cell carcinoma showing in situ and at least superficially invasive growth with features of follicular ameloblastic carcinoma, including islands of epithelial cells lined by peripherally palisading columnar cells (A-B). The ameloblastic component of the lesion is seen to be arising directly from the gingival mucosa (A).

\section{Discussion}

Peripheral ameloblastomas are extremely rare variants of ameloblastomas, constituting $1 \%-2 \%$ of all cases. ${ }^{[3]}$ In a 2001 systematic literature review, Philipsen et al. reported 160 documented cases of peripheral ameloblastomas. ${ }^{[4]} \mathrm{Pe}-$ ripheral ameloblastomas are more predominant in males (1.9:1) with an average age at diagnosis of 52 years compared to 37.4 years in intraosseous ameloblastomas. ${ }^{[4]}$ Additionally, malignant ameloblastomas, which can arise de novo or from a preexisting ameloblastoma, occur in $1.6 \%-2.2 \%$ of all ameloblastomas. ${ }^{[5]}$ Ameloblastic carcinomas arising from peripheral ameloblastomas are exceedingly rare, with only approximately eleven cases of peripheral ameloblastic carcinoma having been reported to date, including one case of an initially benign appearing peripheral ameloblastoma recurring as ameloblastic carcinoma. ${ }^{[4,6-10]}$ Although there have been no prior studies demonstrating the relationship between non-Hodgkin lymphoma or radiation and the development of peripheral ameloblastoma, a retrospective study evaluating 322 non-Hodgkin lymphoma cases found a significantly increased risk for head and neck cancers among patients receiving radiation therapy for early-stage non-Hodgkin lymphoma. ${ }^{[1]}$

Peripheral ameloblastomas typically manifest as slowgrowing, firm, painless masses, which can be sessile or pedunculated with a smooth, granular, or warty surface. ${ }^{[12,13]}$ Peripheral ameloblastomas vary in size but are usually limited to the gingiva without invading the underlying bone. ${ }^{[5]}$ Differential diagnosis includes peripheral giant cell granuloma, peripheral odontogenic fibroma, peripheral ossifying fibroma, papilloma, pyogenic granuloma, epulis, and fibroma. ${ }^{[13-15]}$

Radiological examination may demonstrate superficial cortical bone erosion or depression, which are known as "cupping" or "saucerization". ${ }^{[14,15]}$ However, there may not be any radiographic evidence of bone involvement. ${ }^{[14,15]}$ Histological examination would reveal similar characteristics to intraosseous ameloblastomas. ${ }^{[16,17]}$ According to the World Health Organization, the histological features of the follicular variant of peripheral ameloblastomas include islands of odontogenic epithelium within a fibrous stroma and peripheral palisading basal cells with vacuolated cytoplasm and hyperchromatic nuclei displaced away from the basement membrane. ${ }^{[16,17]}$ The centrally located cells may be loosely arranged, resembling nests of odontogenic stellate reticulum. ${ }^{[16,17]}$ Although several subtypes of ameloblastoma have been documented, the follicular variant is the most common subtype, comprising $29.5 \%$ of all ameloblastomas. ${ }^{[1]}$ Ameloblastic carcinomas combine the histologic characteristics of ameloblastomas with overtly malignant cellular features such as increased nucleus-to-cytoplasm ratio, high mitotic rate, necrosis, calcifications, perineural or vascular invasion, clear cell change, keratin production, nuclear atypia with hyperchromatism, large or atypical nuclei, and irregular nuclear contours. ${ }^{[6]}$

The first-line therapy for peripheral ameloblastomas is conservative supraperiosteal surgical excision with adequate disease-free margins, whereas the first-line therapy for ameloblastic carcinomas is radical surgical excision. ${ }^{[14,18]}$ However, the patient in our case declined surgical excision and will therefore undergo radiation therapy and be followed closely. While a wide range of recurrence rates have been reported for central ameloblastomas based on the extent of the initial resection, the recurrence rate of peripheral ameloblastomas has been reported to be $16 \%-19 \% .{ }^{[4]}$ The recurrence 
rate of ameloblastic carcinomas (both central and peripheral) following radical surgical excision is $28 \% .^{[4,13,18]}$

\section{Conclusion}

Peripheral ameloblastomas are extremely rare, benign odontogenic tumors, constituting $1 \%-2 \%$ of all ameloblastomas.
They undergo malignant transformation in an extremely small number of cases. However, since both recurrence and malignancy have been documented despite resection, long-term follow-up is necessary, especially in cases with features suggestive of malignancy. ${ }^{[13-15]}$

\section{REFERENCES}

[1] Masthan KMK, Anitha N, Krupaa J, et al. J Pharm Bioallied Sci. 2015 Apr; 7 (Suppl 1): S167-S170.

[2] Shahidi Sh, Bronoosh P, Daneshbod Y. Follicular Ameloblastoma Presenting as a Sinonasal Tumor. Iranian Red Crescent Med Journal. 2012; 14(2): 113-116. PMid:22737565.

[3] Kanaparthy R, Kanaparthy A. Amelobalstoma of Gingiva-A Case Report. International Journal of Dental Clinics. 2011; 3(2): 111-112.

[4] Philipsen HP, Reichart PA, Nikai H, et al. Peripheral ameloblastoma: biological profile based on 160 cases from the literature. Oral Oncol. 2001 Jan; 37(1): 17-27.

[5] Rizzitelli A, Smoll NR, Chae MP, et al. Incidence and Overall Survival of Malignant Ameloblastoma. PLoS ONE. 2015; 10(2): e0117789.

[6] Angiero F, Borloni R, Macchi M, et al. Ameloblastic Carcinoma of the Maxillary Sinus. Anticancer Research. 2008; 28: 3847-3854.

[7] Fujita S, Anami M, Satoh N, et al. Cytopathologic Features of Secondary Peripheral Ameloblastic Carcinoma: A Case Report. Diagnostic Cytopathology. 2010; 39(5).

[8] Goda H, Nakashiro K, Ogawa I, et al. Peripheral ameloblastoma with histologically low-grade malignant features of the buccal mucosa: a case report with immunohistochemical study and genetic analysis. International Journal of Experimental Pathology. 2015; 8(2): 20852089.

[9] Kodati S, Majumdar S, Uppala D, et al. Ameloblastic Carcinoma: A Report of Three Cases. Journal of Clinical and Diagnostic Research. 2016 Oct; 10(10): ZD23-ZD25. https://doi.org/10.7860/JC $\mathrm{DR} / 2016 / 21100.8697$

[10] Tajima Y, Kuroda-Kawasaki M, Ohno J, et al. Peripheral ameloblastoma with potentially malignant features: report of a case with special regard to its keratin profile. Journal of Oral Pathology and Medicine.
2001; 30: 494-8. https://doi.org/10.1034/j.1600-0714.20 $01.030008494 . \mathrm{x}$

[11] Kazuma T, Shibuya H, Hayashi K, et al. Radiation-induced cancer after radiotherapy for non-Hodgkin's lymphoma of the head and neck: a retrospective study. Radiat Oncol. 2009; 4: 21. PMid:19591686. https://doi.org/10.1186/1748-717X-4-21

[12] LeCom DW, Bhattacharyya I, Vertucci F. Peripheral Ameloblastoma: A Case Report and Review of the Literature. Journal of Endodontics. Feb 2006; 32(2): 152-154. PMid:16427467. https: //doi.org/10.1016/j.joen.2005.10.028

[13] Bertossi D, Favero V, Albanese M, et al. Peripheral ameloblastoma of the upper gingiva: Report of a case and literature review. J Clin Exp Dent. Apr 2014; 6(2): e180-e184.

[14] Beena VT, Choudhary K, Heera R, et al. Peripheral Ameloblastoma: A Case Report and Review of Literature. Case Rep Dent. 2012; 2012: 571509.

[15] Bhat V, Bhandary SKB, Bhat SP. Extraosseous Ameloblastoma of Maxillary Gingiva-A Case Report. Indian J Surg Oncol. 2014 Sept; 5(3): 211-213. PMid:2541906. https://doi.org/10.1007/s1 3193-014-0328-1

[16] Oteri G, Lentini M, Pisano M, et al. Peripheral Desmoplastic Ameloblastoma in Adolescent Age: Clinico-Pathological and Immunohistochemical Analisys of a Case. Open Dent J. 2014; 8: 159163. PMid:25317210. https://doi.org/10.2174/1874210601 408010159

[17] Gardner DG, Heikinheimo K, Shear M, et al. Classification of Tumours - Pathology \& Genetics. Lyon F.R. IARC Press: Head and Neck Tumours; 2005. World Health Organization; 296-298 p.

[18] Yoon JH, Hong SP, Lee JI, et al. Ameloblastic carcinoma: an analysis of 6 cases with review of the literature. Oral Surgery, Oral Medicine, Oral Pathology, Oral Radiology. 2009; 29: 239-42. https://doi.org/10.1016/j.tripleo.2009.06.045 